\title{
Pablo Neruda viene volando
}

Tuteador del mundo, te ha mirado el ojo calcáreo, y los párpados de la tierra han recibido tu caída, y de eco en eco chillan las más jóvenes montañas. Un peso terrible aplasta el tallo de tu patria, interminables lenguas de fúnebre harina lamen la sombra enrejada de los negros sillones y los tristes regimientos despiertan en los muros de las auroras trágicas los enjambres de la bala, mientras la sal se rasga en las olas alzadas, viajan las cucharas hacia el dolor de las copihuas y el toro clandestino sube a las cordilleras una guitarra blanca...

Hablo de ti, Neruda, a las marchitas hierbas, al almendro que espera su futuro de estrellas, a la mar que recuerda los pies de tu viaje, porque tu voz vivía de salobre magnolia, de altas mujeres marinas destrenzadas y desnudas y del largo vuelo abierto de la gaviota heráldica. $\mathrm{Y}$ hablo de ti, Pablo, a la ausente golondrina, esparzo tu nombre de centella en el aire de la tarde y lo grabo con pistilo amarillo en el silencio del alma. ¡Huérfanas de ti, qué tristes se deshilan las lluvias! Locomotoras grises, tus sollozos pastan, gastados de beso y de ira.

Te me acercas, veloz, vestido de cerezo como un dios ensangrentado que mi mano busca. Desde el corazón de la ceniza, desde tu embudo negro, sé que murmuras aún, de noche y sin estrellas, el breve secreto del trigo que quiere ser campana. Enemigo de la arruga, gran padre seminal de tu verbo paquidérmico, joh ven, entre las rocas, a pronunciar tu sermón de hombre que cree en el árbol! Con corazón sin medallas, tráeme la Cruz del Sur: 
déjala sobre el Carro, siémbrala en nuestro rincón, y haz estallar el ruido de tu risa de velas magallánicas.

Ven con llanto forestal y dulce gemido de corza, hermano de la ternurá solar y taciturna, destructor de columnas, huésped de la materia coronado de halcones y rosales meteóricos. Ven. Hay que hablar todavía, con las manos y la boca, de cómo, entre nosotros, hemos de rehacer todo el hombre y dar un corazón de alondra a la noche que late.

Aún tienes los dedos empolvados de polen. Ven. Leeremos juntos lo que el viento sencillamente escribe sobre las altas piedras. He de subir a tu cara el congregado incendio de la amapola tenaz.

Vivo en medio del invierno, y ya ves que te recuerdo, amigo de un año de México y de un exilio joven; vivo en medio de este canto las raíces y la espuma que juntos compartimos en la dulce luz náhuatl, y alzo el ramo de madrepora que tú me diste un día. Y mientras vienes volando a golpes de ola seca envuelto con sonidos de cometa y palmera, aliso tierra vieja para tus altas mieses, para tus ígneos huesos de lloviznada música, y empuño la caracola, la hoz y la granada.

Porque entre el amaranto hemos de hablar del hombre que se arma en el rocío.

Tú también vienes volando como el Alberto Rojas Jiménez de tu terrestre residencia.

Vienes volando dentro de la tierra como un río de cadenas. Vienes volando, vienes volando, padre del verso innúmero que cerealmente llama a horizontes y ventanas.

Vienes volando, Pablo abierto, negativa de tumba, afónico de tanto grito de azucena cabizbaja.

Más allá del vinagre y los tristes notarios, hecho fénix furioso de febril cabalgata, vienes volando, vienes volando hacia el vino de los orígenes, hacia espigas que inclinan su peso enamorado en mi corazón lacustre. 
¡Vienes volando! Cae el hombre. Y siempre ardes, poeta que atraviesas la niebla por el puente del apio.

Te digo que vienes volando: no quiero que te vuelvas

para contemplar con tu boca tanta sombra de uniforme.

Vienes, vienes volando, hacia el rayo románico

y el ángel acostado de unos pirinecs de sueño.

Vienes volando, amoroso, pesado de cumbre volcánica, con alas de hacha jaspeadas de aurora.

Más arriba, más abajo, entre floridas núbiles, martillos, mimosas, estrellas, cantos ferroviarios, vienes volando empujando la lantísima troica del sol de todos los pueblos.

Vienes volando haciendo silbar tus hondas sinfónicas. Canta un pájaro. Nocturno. Vienes volando. Baja. Escucha. Vienes volando. Tu sombra entra con rumor de vida en la erguida retama. Deja el vuelo entre los tréboles y vamos a compartir el pan y el plenilunio. Vienes llorando. ¡Oh hermano en las lanzas unánimes! Vienes lloviendo elegía e hilada herencia, mientras te quitas la armadura rayada de desastres. Siéntate en esa piedra, no de tropiezo: de espera. La noche ya descubre tu próxima desnudez: seguiremos escribiendo, debajo del olivo, las tablas de la luz... 